\title{
Self-Regulation Approach Supervision in Increasing Work Motivation of Principals
}

\author{
Abu Bakar, \\ ${ }^{1}$ Education Management Departmen, Sekolah Tinggi Ilmu Administrasi, Setih Setio Muara Bungo, Jambi- \\ Indonesia \\ Lias Hasibuan \\ ${ }^{3}$ Education Management Department, Post Graduate, State Islamic University of Sulthan Thaha Saifuddin- \\ Jambi \\ Maisah \\ ${ }^{3}$ Education Management Department, Post Graduate, State Islamic University of Sulthan Thaha Saifuddin- \\ Jambi
}

\begin{abstract}
This study aims to describe the process of self-regulation-based supervision in increasing the work motivation of school principals in Jambi province. Through a qualitative approach, this study involved three school principals as research subjects, namely: the Principal of SMP Negeri 1 Tebo, SMP Negeri 1 Batanghari, and SMP Negeri 1 Muaro Jambi. All data obtained and discussed in this study are qualitative. Based on the data that has been obtained and the description of the discussion above, it can be concluded that supervision with a self-regulatory approach can be carried out well by supervisors by having a positive impact on the principal, namely increasing work motivation. However, in addition to the advantages, supervision with this approach also has drawbacks, therefore, during the implementation of supervision with a self-regulatory approach, supervisors should be able to consider various factors related to the implementation of supervision using this self-regulatory approach can run more effectively. Theoretically, supervisors using this self-regulation approach can be used as an alternative by supervisors in increasing the work motivation of school principals to improve the quality of education.
\end{abstract}

Keywords: Self-Regulation Based Supervision, Principal Work Motivation

DOI: $10.7176 / \mathrm{JEP} / 11-27-18$

Publication date:September $30^{\text {th }} 2020$

\section{Introduction}

In the field of education, the principal has a very strategic war to create organizational work productivity (school). This is because the principal has a big role and responsibility in maintaining and improving the quality of education, as stated by Fitrah (2017) that the principal is because he is the pioneer who drives all changes towards the quality of education. Ekosiswoyo (2016) also said that the principal is one of the key factors in determining the realization of quality education. Likewise, Manora (2019) also states that the role of school principals in improving the quality of education is very important. Then Sayuti (2017), also said that the principal has a very important role in improving the quality of the institution.

Supervision with a self-regulation approach means an activity carried out by a person (supervisor) to seriously supervise and control a job so that it conforms to predetermined standards based on the principal's ability to regulate himself. So that they can maintain their work motivation, manage their own emotions, are resistant to various obstacles/criticism, can manage work independently so that the work can run optimally.

Referring to the explanation above, the focus of this research is to see the implementation of supervision with a self-regulatory approach by supervisors of school principals. This research focuses on the planning process, implementation (weaknesses and strengths), and the results obtained.

\section{Literature Review}

The success of an institution or organization is measured by the achievement of the work program that has been planned. The achievement of work programs is always influenced by the performance of everyone involved in the organization. The higher the performance of each personnel involved, the better work productivity will be and of course organizational productivity or organizational success can be achieved. This is in line with the opinion of Syarif, Sinulingga, and Nazaruddin (2014) that company productivity can be realized by increasing employees' productivity. It is thus clear that in achieving organizational success the role of personnel (employees) is very important and decisive (Busyairi, Ode, and Safar, 2014). 
As has been described above that to achieve the success of an organization, the role of personnel (employees) is very important. Therefore, leaders and supervisors must always pay attention to employee performance so that they have optimal performance. According to Ratnasari (2017) employee performance (work performance) is the result of work in quality and quantity achieved by an employee in carrying out his duties by the responsibilities assigned to him. This means that leaders pay attention to various factors that support employee performance, as an effort to optimize their work productivity to support and ensure organizational productivity as its main goal.

According to Fachreza, Musnadi, and Majid (2018), several factors affect employee performance, including work motivation, work environment, and organizational culture. Meanwhile, Rismayadi (2016) in his research states that age, motivation, and work experience have a positive and significant effect on employee work productivity. Mahendra (2017) in the study also stated that the wage, age, gender, and work experience variables had a positive and significant effect on labor productivity. In line with this opinion, Tanto (2012) also states that the wages received by workers, education, workability, and work discipline have a significant effect on work productivity. In one study, Ukkas (2017) also states that education level, age, work experience, and gender have a significant positive effect on labor productivity. Other research results state that the end of the study was about training variables, employee mental and physical abilities, the relationship between superiors and subordinates (Manik \& Syafrina, 2018). Besides, Nasron and Astuti (2016) also stated that work attitudes, skill levels, labor relations, and organizational leaders, management productivity, personnel efficiency, and entrepreneurship on employee productivity.

Based on the explanation of the research results above, it can be seen that one of the important factors in increasing and maintaining work productivity is work motivation, which is the encouragement of a series of human behavior processes in achieving goals (Theodora, 2015). Erica, Suryani, Hoiriah, and Vidada (2020) state that motivation is an impulse from within humans to take any action where the action is deemed to provide something that is needed or expected, thus motivation can arise if there is an interaction between the person and someone who other or an environment that can move itself to do something. This is empirically proven by the results of research by several experts, for example, Murti and Srimulyani (2013), who found that motivation has a significant effect on job satisfaction, motivation has no significant effect on employee performance and job satisfaction has a significant effect on employee performance. This finding is also reinforced by the results of research after Nurcahyani and Adnyani (2016) who found that motivation has a positive and significant effect on job satisfaction. Thus, the research results of Arianto and Kurniawan (2020) show that motivation and work environment have a partial or simultaneous influence, whereas from the correlation results, motivation and work environment have a very strong relationship to performance. Thus the leadership of the organization must be able to maintain the work motivation of each person to create better organizational work productivity.

Besides, Mohammady (2018) describes in more detail the role of the principal, namely: (1) the principal as a manager, (2) the principal as an educator, (3) the principal as a supervisor. This is also in line with the opinion of Sudrajat (2008) that efforts to improve teacher competence can be made through optimizing the role of school principals, as educators, managers, administrators, supervisors, leaders, creators of work climate, and entrepreneurs. Waston and Taryanto (2019) also state that the role of the principal in improving the quality of education can be done by 1) increasing teacher professionalism, 2) improving the quality of learning, 3) improving facilities and infrastructure, 4) increasing student learning motivation.

Regarding the responsibility of school principals, Julaiha (2019) states that school principals are responsible for the success of education by implementing school administration with all its substance, besides that the principal is responsible for the quality of existing resources so that they can carry out tasks by the duties and functions of each. Therefore, school principals are required to have various abilities, both related to management and leadership issues, to develop and advance their schools in an effective, efficient, independent, productive and accountable manner (Tarhid, 2017). Nai and Wijayanti (2018) also stated that the principal as the leader in the school has an important responsibility in his efforts to realize the vision, mission, and goals of the school. Thus, Dalanggo (2019) suggests that a principal should master leadership techniques to be able to carry out his duties effectively.

Referring to the description above, which is related to organizational productivity, the urgency of work motivation, and the strategic role of the principal in creating school work productivity, it can be understood that the principal should have high work motivation to improve school quality and productivity. This is very important considering that the duties and responsibilities of the principal are included in the heavy category. Thus, school principals must professionally receive sufficient guidance so that they have good work motivation so that they can achieve and carry out their tasks perfectly. This is in line with the writing of Maryadi (2014) that motivation is the provision of a driving force that creates someone's excitement so that they are willing to work together, work effectively, and be integrated with all their efforts to achieve satisfaction.

School supervisors have an important role in fostering school principals so that they have good work motivation. School supervisors are professional educational personnel who are given full responsibility, duties, 
and authority by the authorized official to carry out guidance and supervision in the academic and managerial fields (Messi, Anggita Sari, Anggita Sari, Murniyati, \& Murniyati, 2018). The supervisory task is the whole activity of supervising, checking, matching, and controlling all activities so that they take place by the established plan and the desired results (Iin, 2018). This was also conveyed by Rahmah (2018) that in the course of the education process, supervisors or supervisors are an integral part of improving learning achievement and school quality. Therefore, by the regulations that every supervisor (in Indonesia) must have 6 compulsory competencies, namely: (1) personality, (2) social, (3) academic supervision, (4) managerial supervision, (5) evaluation education, and (6) research and development.

Regarding the supervision process in schools, school supervisors have two main supervisory duties, namely, managerial supervision and academic supervision. Managerial supervision to improve school management through increasing the administrative capacity of education personnel or other school resources in carrying out tasks and obligations that support the implementation of the learning process and quality improvement in schools, while academic supervision is an effort made by supervisors to monitor the course of the learning process in a school. and assessing teacher performance in conducting teaching activities (Sari, Bafadal, \& Wiyono, 2018). School control or supervision is carried out not solely intended to find and correct mistakes, but rather to prevent mistakes (Iin, 2018). Thus, supervision must be carried out in a coordinated manner, because it carries out supervision by observing all organizational activities to ensure that all work carried out goes according to a predetermined plan (Rahmah, 2018).

As mentioned above, one of the duties of supervisors is to carry out managerial supervision. Managerial supervision is an effort to provide assistance provided by supervisors to educators and education personnel in the framework of coaching, assessment, and guidance starting from program plans, processes, to evaluations, results, and activity reports (Sari et al., 2018). In carrying out his duties and responsibilities, a school supervisor is given the authority to (1) select and determine work methods to achieve optimal results in carrying out tasks as well as possible by the professional code of ethics; (2) determine the level of performance of teachers and other supervised personnel and the factors that influence it, and (3) determine and or propose a coaching program and conduct coaching (Nur, 2010).

Based on the description above, it can be understood that in carrying out their duties, a supervisor is given the authority or freedom to choose and determine the coaching method and propose a coaching program. Thus, a supervisor should be able to design an appropriate coaching approach so that the supervision process can run effectively with optimal results. An innovative supervisory approach is needed so that school principals as the target of coaching are actively involved in the process so that the performance and work motivation of school principals in running educational organizations can run dynamically.

According to several types of research, to generate productivity, independence, and work motivation is a selfregulatory approach. This can be seen from the results of research by Yasdar and Muliyadi (2018). The application of Self-Regulation Techniques has a positive effect on learning independence. Pattynama, Sahrani, and Heng (2019) also found that students with good self-regulation would be more successful in their academics. This finding is also supported by the results of research by Kusaeri and Mulhamah (2016) that a student who has good selfregulation skills will do better in mathematics. Besides, Kusumadewi (2011) also found that individuals with good self-regulation abilities tend to have a good quality of life, even though they are in a bad situation. Thus it can be understood that self-regulation has a positive impact on oneself to increase self-motivation and work productivity. Therefore, self-regulation is believed to be adapted in the process of supervision by supervisors of school principals.

\section{Research Method}

This research is field research, which is a research conducted directly with the object of research and a data collection is carried out in the field using a qualitative approach. This is in line with Rahmat's (2009) opinion that qualitative research is research that requires researchers to go to the field, interact with them, strive to understand their language and interpretations of the world around them, make observations, and explore. Thus, the data obtained, analyzed, and presented in this study are qualitative data. According to Sugiyono (2018), qualitative data is data that is expressed in the form of words, sentences, and pictures. In this study, the data were obtained based on a literature review, information, and discuss results with the respondent, in this case, the principal. Methods of data collection in this study through interviews, observation, and documentation. The research was conducted at SMP Jambi Province, namely SMP Negeri 1 Tebo, SMP Negeri 1 Batanghari, and SMP Negeri 1 Muaro Jambi. The analysis used is interactive analysis, with three components, namely data reduction, data presentation, and conclusion drawing. This is as stated by Rijali (2019) that data reduction is an attempt to infer data, then sorting the data into certain conceptual units, certain categories, and certain themes. Besides, the data obtained were also explored through content analysis activities, namely to determine trends in communication content. Two approaches are often used, namely quantitative content analysis and qualitative content analysis (Ahmad, 2018). 


\section{Result and Discuss}

Conceptually, the word "supervision" has been mentioned in the Indonesian dictionary to mean primary supervision or the highest control. As in the English Dictionary, the word "supervision" means to supervise something. Thus, supervision means an activity carried out by a person (supervisor) to seriously supervise and control a job so that it conforms to predetermined standards. The word "self-regulation" or self-regulation can be defined as self-regulation that involves controlling one's behavior, emotions, and thoughts in pursuit of long-term goals. More specifically, emotional self-regulation refers to the ability to manage disturbing emotions and urges. McClelland, Wanless, and Lewis, (2016) stated that self-regulation is an important component of healthy development throughout life and has been associated with a variety of outcomes including short and long-term educational success. Lord, Diefendorff, Schmidt, \& Hall, (2010) also explain that self-regulation includes "the processes involved in achieving and maintaining (i.e., maintaining orderly) goals, in which goals are represented internally (i.e., within) circumstances desired ". Thus it can be understood that the concept of supervision with a self-regulation approach means an activity carried out by a person (supervisor) to seriously supervise and control a job so that it conforms to predetermined standards based on the principal's ability to regulate himself. So that they can maintain their work motivation, manage their own emotions, are resistant to various obstacles/criticism, can manage work independently so that the work can run optimally.

Referring to the definition above, it can be understood that supervision with a self-regulatory approach is one of the new ideas in supervision activities. As a new idea, the supervision approach needs to be researched more comprehensively to see its impact on the field empirically. For this reason, supervision with a self-regulatory approach is an alternative approach for supervisors to carry out their duties. By the opinion of Sabandi (2013) that Supervisors must choose an approach on a case-by-case basis, use the knowledge base to classify teachers, observe and interact with current teachers or groups, and analyze the current situation. This is very important given that supervision is a major feature of professional development in many professions (Youngstrom \& Gentile, 2018).

Supervise with a self-regulation approach has been implemented professionally in a qualitative study by supervisors in Jambi Province, with trials at three junior high schools (SMP), namely, SMP Negeri 1 Tebo, SMP Negeri 1 Batanghari, and SMP Negeri 1 Muaro Jambi. During the supervising process with a self-regulatory approach carried out by supervisors, the principal enthusiastically participated in the activity. The real results or impacts of the implementation of supervision using the self-regulation approach of the three school principals are as follows:

Table 1. Qualitative Impact of implementation of Self-Regulation Approach Supervision

\begin{tabular}{|c|c|c|}
\hline No & The School & The Impact \\
\hline 1 & $\begin{array}{l}\text { SMP Negeri } 1 \\
\text { Tebo }\end{array}$ & $\begin{array}{l}\text { 1. Work activities with colleagues and education offices are getting better and closer } \\
\text { 2. The principal can forge an active, harmonious working relationship with the teacher through } \\
\text { involvement in every activity in the school. Working relationships with supervisors are also } \\
\text { actively and harmoniously fostered to make work comfortable when the principal is included } \\
\text { in the school work team. } \\
\text { 3. Principals are better able to plan work independently } \\
\text { 4. The principal can carry out what work has been planned effectively and efficiently by his } \\
\text { duties and responsibilities. } \\
\text { 5. The principal can perform monitoring and evaluation well, meaning that the principal is } \\
\text { always monitoring the implementation of his work if it is as planned and targeted, as well as } \\
\text { evaluating the results of his work. } \\
\text { 6. The principal can carry out the preparation of activity reports accurately, meaning that the } \\
\text { principal always documents and reports the results of his work }\end{array}$ \\
\hline 2 & $\begin{array}{l}\text { SMP Negeri } 1 \\
\text { Batanghari }\end{array}$ & $\begin{array}{l}\text { 1. Coordination between school principals, vice-principals, teachers and staff is getting better } \\
\text { 2. The working relationship between the principal, supervisors, and the education office is } \\
\text { getting more harmonious } \\
\text { 3. The teacher is also able to accept the head as an active, creative, and productive leader } \\
\text { 4. Positive communication principals apply by using polite language and polite behavior } \\
\text { 5. The principal's ability to manage and lead the school increases }\end{array}$ \\
\hline 3 & $\begin{array}{l}\text { SMP Negeri } 1 \\
\text { Muaro Jambi }\end{array}$ & $\begin{array}{l}\text { 1. The school management process is getting better, the distribution of jobs is evenly distributed, } \\
\text { all components of the school are involved in decision making } \\
\text { 2. The principal's attention to the rights of teachers and employees is getting better, promotions and } \\
\text { career paths for teachers and staff are going well. } \\
\text { 3. Principals can compile activity reports systematically, effectively, and independently. } \\
\text { 4. The principal is better able to build productive communication with parties outside the school } \\
\text { (supervisors, education offices, school committees, and NGOs). }\end{array}$ \\
\hline
\end{tabular}


Based on the data as shown in Table 1 above, it can be seen that supervision with a self-regulation approach has a positive impact on increasing work motivation of school principals. This is based on the impact seen during and after the supervision process took place by supervisors to the school principal. Thus, supervision with a selfregulation approach can be used as an alternative for school supervisors in fostering school principals to increase school principal work motivation.

Also, the data obtained in this study were in the form of advantages and disadvantages of supervision with a self-regulatory approach. Based on the results of observations during the implementation of supervision, data were obtained about the advantages of this supervisory approach, including 1) able to increase the principal's work motivation, 2) able to build the principal's self-confidence, 3) able to build a more harmonious relationship between principals and supervisors. ,4) the independence of the principal in managing and doing tasks increases. The weaknesses of supervision with this self-regulatory approach include: 1) it requires supervisors who understand the concept of self-regulation well, 2) the implementation of supervision is relatively longer because the focus of this coaching is to foster the ability to self-regulate personally, 3) it requires proper supervision planning more complex.

Based on the above advantages and disadvantages, it can be understood that supervision with a self-regulation approach has several advantages and disadvantages. With these advantages, the supervision model needs to be maintained and developed, while the existing weaknesses, it is necessary to find a solution so that the implementation of supervision with this model can run better. Conceptually, the advantages and disadvantages will always be owned by a supervised model. Therefore, objectively, the weaknesses that exist in the supervision model are still understandable.

\section{Discussion}

Based on the data obtained in the study as described above, it appears that the supervision using the selfregulation approach has a positive impact on the work motivation of school principals. These positive impacts include: 1) being able to increase the principal's work motivation, 2) being able to build the principal's selfconfidence, 3 ) being able to build a more harmonious relationship between the principal and supervisors, 4) the independence of the principal in managing and doing tasks increased. This proves that supervision with a selfregulation approach can continue to be developed and used as an alternative in the education supervision process to improve the quality of education.

The implementation of self-regulation approaching supervision carried out by school supervisors in Jambi province involving three school principals was carried out with the main activities in the form of: 1) providing directions and asking for programs that have been made by the school principal then providing input on improvements (program reflection), 2) mentoring preparation of school work programs, especially those related to the fulfillment of National Education Standards, 3) monitoring the implementation of content standards, process standards, competency standards for educators and education personnel standards, facilities and infrastructure standards, management standards, financing standards and applied educational assessment standards, 4 ) strengthening the design of school activities, evaluating the leadership pattern of school principals, information systems and management, 5) carrying out activities of mentoring and professional training of teachers and heads covering both academic and managerial fields. The supervision activities that have been carried out are in line with the opinion of Slameto (2016), that the implementation of supervision must include program preparation, program implementation, program evaluation. Thus, the implementation of supervision has been good.

As stated by Latham and Locke, (1991), that self-regulation can be increased through goal setting. Therefore, the supervisory process with a self-regulatory approach also begins by establishing educational goals, supervision, and school goals (vision-mission) which are set together. Through this activity, it also aims to build positive relationships between school principals and supervisors. It is through this factor that ultimately fosters work motivation for school principals. This is as stated by Eccles \& Wigfield, (2002), Baumeister \& Vohs (2007), and Zimmerman (2008) that there is a relationship between self-regulation and self-motivation.

Besides, the supervision carried out was in a self-regulation approach, so during the implementation of supervision, all activities were carried out using a self-regulation approach, which involved emotional and cognitive aspects of the regulatory behavior of the principal. This is in line with the opinion of McClelland et al., (2016) that self-regulation includes emotional and cognitive aspects of the regulatory behavior of principals. During the implementation of supervision, supervisors also consider involving personal experiences (supervisors and school principals) to ensure the effectiveness and efficiency of the supervision. This is also in line with the opinion of Lord et al., (2010) that self-regulation in the workplace is understood as an internal process that occurs from time to time. 
As the data in Table 1 above shows, that there is a positive impact from the implementation of supervision with a self-regulatory approach. It also indicates that the supervision process which aims to coordinate educational programs has been going well. This is by the opinion of Iin (2018) that coordinating all programs to be implemented by educational institutions. 1) enriching the experience of the leadership of educational institutions, 2) equipping the leadership of educational institutions, 3) stimulating creative efforts in education, 4) providing facilities for work program implementers, 5) providing a continuous assessment of the performance of educational program implementers.

Based on the data that has been obtained (Table 1), it shows that supervision with a self-regulation approach can increase work activities with colleagues and education offices to get better and closer and increase actively and harmoniously. This means that there has been an increase in the involvement of each component of the school is running an organization dominated by the principal. The situation shows that there has been an increase in motivation, the self-confidence of the principal, and the ability to manage organizational resources to be more productive so that it has an impact on the work productivity of all school elements.

From the research data above, it can also be seen that supervision with a self-regulation approach has an impact on increasing the ability of school principals to plan plans for work that is done independently. The independence of school principals in preparing educational planning in schools is also evidence of the growing motivation of school principals which of course will have an impact on work productivity. This is also in line with the opinion of Kurniawan (2018) that motivation and work discipline simultaneously on employee productivity with a positive correlation. This situation is of course the result of this process of supervision approached by self-regulation.

Also, the positive impact that occurs on school principals (table 1) includes that the principal can conduct monitoring and evaluation well, meaning that the principal is always monitoring the implementation of his work whether it is as planned and targeted, also evaluates the results of his work and can carry out the preparation of activity reports carefully, meaning that the principal always documents and reports the results of his work. In general, this is the principal managerial ability that every school principal must have in leading educational institutions. Therefore, this increase in ability also means that supervision with a self-regulation approach is also proven to be able to increase the competence of school principals.

Thus, supervision with a self-regulation approach is empirically proven to be able to achieve the goals of the supervision itself. Therefore, this supervision model can be used as an alternative for supervisors in carrying out supervision activities to increase the work motivation of school principals.

\section{Conclusion}

Based on the data that has been obtained and the description of the discussion above, it can be concluded that supervision with a self-regulatory approach can be carried out well by supervisors by having a positive impact on the principal, namely increasing work motivation. However, in addition to the advantages, supervision with this approach also has drawbacks, therefore, during the implementation of supervision with a self-regulatory approach, supervisors should be able to consider various factors related to the implementation of supervision using this selfregulatory approach can run more effectively. Theoretically, supervisors using this self-regulation approach can be used as an alternative by supervisors in increasing the work motivation of school principals to improve the quality of education.

\section{Acknowledgment}

This research was carried out due to the contributions of various parties who actively support and facilitate this research. Therefore, the authors would like to express their gratitude and high appreciation to all parties involved in this research. High gratitude and appreciation are conveyed to the postgraduate program of the State Islamic University of Sulthan Thaha Saifuddin, Jambi who has provided the opportunity to pursue a doctoral program. Furthermore, the principals of SMP Negeri 1 Tebo, SMP Negeri 1 Batanghari, and SMP Negeri 1 Muaro Jambi as well as school supervisors from each of these schools have been willing to become respondents in this study. Hopefully, this research will be useful, both conceptually and empirically in the future.

\section{References}

Ahmad, J. (2018). Desain Penelitian Analisis Isi (Content Analysis). Researchgate. https://doi.org/10.13140/RG.2.2.12201.08804

Arianto, N., \& Kurniawan, H. (2020). Pengaruh Motivasi dan Lingkungan Kerja Terhadap Kinerja Karyawan. JENIUS (Jurnal Ilmiah Manajemen Sumber Daya Manusia). https://doi.org/10.32493/jjsdm.v3i3.4869 
Baumeister, R. F., \& Vohs, K. D. (2007). Self-Regulation, Ego Depletion, and Motivation. Social and Personality Psychology Compass. https://doi.org/10.1111/j.1751-9004.2007.00001.x

Busyairi, M., Ode, L., \& Safar, A. (2014). Produktivitas Kerja Karyawan. Jurnal Ilmiah Teknik Industri.

Dalanggo, H. (2019). Strategi Perencanaan Supervisi Akademik Kepala Madrasah. Ideas: Jurnal Pendidikan, Sosial Dan Budaya. https://doi.org/10.32884/ideas.v5i4.226

Eccles, J. S., \& Wigfield, A. (2002). Motivational beliefs, values, and goals. Annual Review of Psychology. https://doi.org/10.1146/annurev.psych.53.100901.135153

Ekosiswoyo, R. (2016). Kepemimpinan Kepala Sekolah yang Efektif Kunci Pencapaian Kualitas Pendidikan. Jurnal Ilmu Pendidikan. https://doi.org/10.17977/jip.v14i2.24

Erica, D., Suryani, I., Hoiriah, \& Vidada, I. A. (2020). Pengaruh Motivasi terhadap Kinerja Karyawan Pada PT Aneka Gas Industri Tbk. Jurnal Ecodemica, Vol. 4 No. 1 April 2020.

Fachreza, Musnadi, S., \& Majid, M. S. A. (2018). Pengaruh Motivasi kerja, lingkungan kerja, dan budaya organisasi terhadap kinerja karyawan dan dampaknya pada kinerja Bank Aceh Syariah di Kota Banda Aceh. Jurnal Magister Manajemen.

Fitrah, M. (2017). Peran Kepala Sekolah Dalam Meningkatkan Mutu Pendidikan. Jurnal Penjaminan Mutu. https://doi.org/10.25078/jpm.v3i1.90

Iin, M. (2018). Pengawasan (Controlling) Dalam Institusi Pendidikan. Jurnal Lmiah Pendidikan Agama Islam.

Julaiha, S. (2019). Konsep Kepemimpinan Kepala Sekolah. Tarbiyah Wa Ta'lim: Jurnal Penelitian Pendidikan Dan Pembelajaran. https://doi.org/10.21093/twt.v6i3.1734

Kurniawan, P. (2018). Pengaruh Motivasi Dan Disiplin Kerja Terhadap Produktifitas Kerja Karyawan Pada Pt. Daya Perkasa. Jurnal Mandiri. https://doi.org/10.33753/mandiri.v2i2.46

Kusaeri, K., \& Mulhamah, U. N. (2016). Kemampuan Regulasi Diri Siswa dan Dampaknya Terhadap Prestasi Belajar Matematika. Jurnal Review Pembelajaran Matematika. https://doi.org/10.15642/jrpm.2016.1.1.3142

Kusumadewi, M. D. (2011). Peran Stresor Harian, Optimisme Dan Regulasi Diri Terhadap Kualitas Hidup Individu Dengan Diabetes Melitus Tipe 2. Psikoislamika: Jurnal Psikologi Dan Psikologi Islam. https://doi.org/10.18860/psi.v0i1.1545

Latham, G. P., \& Locke, E. A. (1991). Self-regulation through goal setting. Organizational Behavior and Human Decision Processes. https://doi.org/10.1016/0749-5978(91)90021-K

Lord, R. G., Diefendorff, J. M., Schmidt, A. M., \& Hall, R. J. (2010). Self-regulation at work. Annual Review of Psychology. https://doi.org/10.1146/annurev.psych.093008.100314

Mahendra, A. D. (2017). Analisis Pengaruh Pendidikan, Upah, Jenis Kelamin, Usia Dan Pengalaman Kerja Terhadap Produktivitas Tenaga Kerja (Studi di Industri Kecil Tempe di Kota Semarang). In Skripsi.

Manik, S., \& Syafrina, N. (2018). Faktor-faktor yang mempengaruhi produktivitas kerja karyawan pada bank danamon simpan pinjam. Jurnal Kajian Ekonomi Islam (Maqdis).

Manora, H. (2019). Peranan Kepala Sekolah Dalam Meningkatkan Mutu Pendidikan. Edification Journal. https://doi.org/10.37092/ej.v1i1.88

Maryadi, M. (2014). Pengaruh Motivasi, Diklat, Ilkim Organisasi, Komptensi Terhadap Kinerja Dosen Perguruan Tinggi Swasta Kopertis Wilayah VI Jawa Tengah. Malih Peddas (Majalah Ilmiah Pendidikan Dasar). https://doi.org/10.26877/malihpeddas.v2i1.497

McClelland, M. M., Wanless, S. B., \& Lewis, K. W. (2016). Self-Regulation. In Encyclopedia of Mental Health: Second Edition. https://doi.org/10.1016/B978-0-12-397045-9.00038-0

Messi, M., Anggita Sari, W., Anggita Sari, W., Murniyati, M., \& Murniyati, M. (2018). Pelaksanaan Supervisi Akademik Pengawas Sekolah Sebagai Upaya Peningkatan Profesionalisme Guru. JMKSP (Jurnal Manajemen, Kepemimpinan, Dan Supervisi Pendidikan). https://doi.org/10.31851/jmksp.v3i1.1583

Mohammady, Z. A. (2018). Peran Kepala Sekolah Dalam Mengembangkan Mutu Budaya Organisasi. Muslim Heritage. https://doi.org/10.21154/muslimheritage.v2i2.1118

Murti, H., \& Srimulyani, V. A. (2013). Pengaruh Motivasi Terhadap Kinerja Pegawai Dengan Variabel Pemediasi Kepuasaan Kerja Pada Pdam Kota Madiun. JRMA Jurnal Riset Manajemen Dan Akuntansi.

Nai, H., \& Wijayanti, W. (2018). Pelaksanaan tugas dan fungsi kepala sekolah pendidikan menengah negeri. Jurnal Akuntabilitas Manajemen Pendidikan. https://doi.org/10.21831/amp.v6i2.10182 
Nasron, \& Astuti, T. B. (2016). Faktor-Faktor Yang Mempengaruhi Produktivitas Kerja (Studi Pada Karyawan Bagian Produksi PT Mazuvo Indo). Jurnal Kajian Akuntansi Dan Bisnis.

Nur, M. T. (2010). Optimalisasi Peran Pengawas Sekolah dan Fasilitasi Oleh Lembaga Penjaminan Mutu Pendidikan [Optimization of Role of School Supervisor and Facilitation of Education Quality Assurance Board]. Jurnal Guru Membangun.

Nurcahyani, N., \& Adnyani, I. (2016). Pengaruh Kompensasi Dan Motivasi Terhadap Kinerja Karyawan Dengan Kepuasan Kerja Sebagai Variabel Intervening. E-Jurnal Manajemen Universitas Udayana.

Pattynama, P. C., Sahrani, R., \& Heng, P. H. (2019). Peran Regulasi Diri Dalam Belajar Dan Keterlibatan Akademik Terhadap Intensi Mengundurkan Diri Dengan Resiliensi Sebagai Mediator. Jurnal Muara Ilmu Sosial, Humaniora, Dan Seni. https://doi.org/10.24912/jmishumsen.v1i1.5629

Rahmah, S. (2018). Pengawas Sekolah Penentu Kualitas Pendidikan. JURNAL TARBIYAH. https://doi.org/10.30829/tar.v25i2.378

Rahmat, P. S. (2009). Penelitian Kualitatif. Journal Equilibrium.

Ratnasari, K. C. K. R. T. (2017). Evaluasi Kinerja Sumber Daya Manusia. In Evaluasi Kinerja Sumber Daya Manusia. https://doi.org/10.1017/CBO9781107415324.004

Rijali, A. (2019). Analisis Data Kualitatif. Alhadharah: Jurnal Ilmu Dakwah. https://doi.org/10.18592/alhadharah.v17i33.2374

Rismayadi, B. (2016). Faktor-Faktor Yang Mempengaruhi Produktivitas Karyawan (Studi Kasus pada CV Mitra Bersama Lestari Tahun 2014). Jurnal Manajemen \& Bisnis Kreatif. https://doi.org/10.36805/manajemen.v1i1.53

Sabandi, A. (2013). Supervisi Pendidikan Untuk Pengembangan Profesionalitas Guru Berkelanjutan. Jurnal Ilmiah Ilmu Pendidikan.

Sari, D. N. A., Bafadal, I., \& Wiyono, B. B. (2018). Pelaksanaan Supervisi Manajerial Dalam Rangka Implementasi Manajemen Berbasis Sekolah. Jurnal Administrasi Dan Manajemen Pendidikan. https://doi.org/10.17977/um027v1i22018p213

Sayuti, F. (2017). Peran Kepala Sekolah Dalam Peningkatan Mutu Pendidikan Islam. FIKROTUNA. https://doi.org/10.32806/jf.v3i1.2714

Slameto, S. (2016). Supervisi Pendidikan Oleh Pengawas Sekolah. Kelola: Jurnal Manajemen Pendidikan. https://doi.org/10.24246/j.jk.2016.v3.i2.p192-206

Sudrajat, A. (2008). Peran Kepala Sekolah dalam Meningkatkan Kompetensi Guru. Pendidikan.

Sugiyono. (2018). Metode Penelitian Kuantitatif,Kualitatif dan R\&D. Ke-26.

Syarif, A. A., Sinulingga, S., \& Nazaruddin. (2014). produktivitas. Teknovasi.

Tanto, E. A. (2012). Faktor-faktor yang mempengaruhi produktivitas pekerja pada pengerjaan atap baja ringan di perumahan green hills malang. Jurnal Rekayasa Sipil.

Tarhid, T. (2017). Kepemimpinan Kepala Sekolah dalam Meningkatkan Profesionalisme Guru. Jurnal Kependidikan. https://doi.org/10.24090/jk.v5i2.1931

Theodora, O. (2015). Pengaruh Motivasi Kerja Terhadap Kinerja Karyawan PT. Sejahtera Motor Gemilang. Agora.

Ukkas, I. (2017). Faktor-Faktor Yang Mempengaruhi Produktivitas Tenaga Kerja Industri Kecil Kota Palopo. Kelola: Journal of Islamic Education Management. https://doi.org/10.24256/kelola.v2i2.440

Waston, W., \& Taryanto, T. (2019). Peran Kepala Sekolah Dalam Meningkatkan Mutu Pendidikan Di Sekolah Dasar Islam Terpadu Muhammadiyah Jumapolo Karanganyar. Profetika Jurnal Studi Islam. https://doi.org/10.23917/profetika.v0i0.8949

Yasdar, M., \& Muliyadi, M. (2018). Penerapan Teknik Regulasi Diri (self-regulation) untuk Meningkatkan Kemandirian Belajar Mahasiswa Program Studi Bimbingan Konseling STKIP Muhammadiyah Enrekang. Edumaspul - Jurnal Pendidikan. https://doi.org/10.33487/edumaspul.v2i2.9

Youngstrom, M. J., \& Gentile, P. A. (2018). Supervision. In Willard and Spackman's Occupational Therapy, 13th Edition. https://doi.org/10.1192/apt.5.2.83

Zimmerman, B. J. (2008). Investigating self-regulation and motivation: Historical background, methodological developments, and prospects. American Educational Research Journal. https://doi.org/10.3102/0002831207312909 